\title{
Gram Negative Bacillus
}

National Cancer Institute

\section{Source}

National Cancer Institute. Gram Negative Bacillus. NCI Thesaurus. Code C86421.

Any rod shaped bacteria that contains low levels of peptidog lycan in its cell wall and stains pink with the Gram staining technique. 